\title{
The concept of assessing the City Council management control level for ef- fective decision making
}

\author{
Tetiana Melikhova ${ }^{1, *}$ and Olena Mikhailutsa ${ }^{1, * *}$ \\ ${ }^{1}$ Zaporizhzhia National University, 66 Zhukovkoho Str., Zaporizhzhia, 69600, Ukraine
}

\begin{abstract}
.
In present paper, time series models of revenues and expenses of general and special local budget fund in Zaporizhzhia City Council for 2017-2020 are built. The possibility of forecasting time series has been investigated on the example of local budget revenues and expenses. The concept of assessing the level of management control which consists of information-analytical circuit, analysis and modeling circuit, and decision-making circuit has been proposed. The best options for absolute and comparative economic efficiency of accounting and economic expenses of management control have been substantiated. The forecast for calculating the absolute and comparative economic efficiency of management control on the data of Zaporizhzhia City Council is shown and the annual economic effect from its implementation is calculated. The methodological approaches to the analysis of income and expenses of the general and special fund have been improved. They, unlike existing methods, include time series modeling and studies describing complex changes in parameters over time. This made it possible to carry out high-quality management control and increase the efficiency of activities. The SPSS Statistics data analysis package is used for data processing, test assumption and building the future strategy.
\end{abstract}

\section{Introduction}

Successful management in the system of economic relations is directly dependent on specific conditions. The volatility in the financial sector in regions influences the growth in production expenses of enterprises, caused by increases in fuel, electricity and gas tariffs. The global financial crisis due to currency fluctuations negatively affects the confidence of individuals and legal entities in banks. Quarantining of establishments led to a halt of small and medium-sized businesses. Bankruptcy of banking institutions in previous years has increased the distrust of deposits and loans. Under current circumstances effective management of local authorities is becoming a priority. The dynamic operating conditions in the region with many different external and internal threats encourage the study of the conceptual frameworks of management control.

The modern concept of management accounting in the scope of control entered the theory and practice as a new concept of information and management - management control (controlling - in Germany, control de jestion - in France). Management control is an integral element of management process, it is control over the economic management, and not the management of activities for control. One of the main incentives for its implementation is the uncertainty of the results inherent in any type of activity that are envisaged, planned and designed. Striving for control unification corresponds to the desire for the integration

\footnotetext{
*e-mail: tanyu_zp_zgia@ukr.net

**e-mail: elenamikhaylutsa7@gmail.com
}

of measures and weights in all countries, that is, it would be very important to have a generally recognized system of management control.

The implementation of local government activities is impossible without hazards, therefore, special attention of the management should be aimed at preventing such threats, as well as leveling their consequences. Optimization of resources and conducting of monitoring efforts aimed at the effective and stable operation of local council bodies, and risk management are approaches to the need for internal control. The systematic implementation of internal control is one of important management functions of the local council body. The control function involves the verification of planned and actually revenues and expenses incurred for general and special funds. Monitoring the optimal use of local budget funds, competent management of financial resources, rapid response to threats to minimize and prevent harm ensure effective city management.

\section{Literature review}

The main issues addressed in this paper are based on review and analysis of foreign and domestic publications. Information and analytical support of management control has been the subject of numerous studies during last decades in developed and developing countries. Definition of management control, as a process due to which managers ensure that resources come and are used efficiently and effectively to achieve the objectives set for the organization, is presented by S. Gschwantner and M. Hiebl [1]. 
Indeed, any research is based on the study of the conceptual and categorical apparatus. In foreign sources, management control is described as a function aimed at achieving certain goals within the established schedule. This process has three main components, such as taking corrective action, measuring of actual productivity and standardsetting. Management control is defined as a process that helps to achieve objectives of the organization [2]. But the author did not single out the functions of the management control itself. All functions of management control are important and closely interact with each other, passing into each other.

R. Savchenko and N. Savchenko believe that any economic entity operates under uncertainty, and the main task of managers and owners of an enterprise is to assess the uncertainty level and to make appropriate management decisions to achieve the strategic objectives. At the same time, the achievement of both strategic and operational objectives of enterprise under conditions of uncertainty and permanent risks is facilitated by the management control system. The presented classification division of management control [3] made it possible to prove the feasibility of identifying varieties of control depending on the levels of making management decisions.

However, a prerequisite for ensuring management control is the adoption of effective management decisions based on timely prevention and checking errors of accounting objects [4]. But the content of the author's definition of management control is very similar to the interpretation of internal accounting control. The threat of committing violations and mistakes can happen by the coincidence of subjective factors (conducting ineffective corporate management) and objective ones (changes in legislation, economic crisis). Based on a literature survey of the impact of management control, the authors [5] identified several factors that can affect the management control systems and activities of organizations.

Also, numerous factors enabling the correct focus of the management control system on management decisionmaking are provided as well. However, the author did not correctly identify the factors that positively or negatively affect the conduct of management control and management decision-making.

The study of management control features can be found in works of such scientists as S. Saliga [6], K. Saliga [7], Yu. Yarashykly [8], E. Antipenko [9] and others. The results of management control depend on its effectiveness. It is necessary to compare the benefits received and the expenses incurred to calculate the effectiveness of their implementations [8]. Especially noteworthy is the reasonable calculation of economic efficiency. The authors [6] developed a system of indicators to assess financial security and tax audit effectiveness, that is based on the principles for assessing the quality and effectiveness of tax audit as a financial security component and cost-benefit studies of economic activities of enterprises. The concept proposed by the author can be used to calculate the economic efficiency of any control object. Detailed consideration of the principle of economic efficiency assessment of the enterprise is given by K. Saliga. In [7] he analyzes the re- lationship of the indicator to the nature and effect of economic laws, correlation of economic efficiency indicators of production at the levels of the national economy and the economic entity, consistency, logical coherence, the link with partial indicators of economic efficiency, interdependence of changing indicators based on trends of living and materialized labor, making production self-sustainable as a constraint on changes in private performances, full accounting of production expenses and results, their correspondence to each other in time and content, embrace of all types of enterprise activities, availability of criteria for determination of private generalized productive indicators, efficiency of using all types of advanced, applied and used resources, the focus on achieving the main (general) production objective, logistic approach to assessing enterprise productivity, quantitative measurability of indicators and performance criteria and comparability of the options. So, the author is a well-grounded study based on the foundations of economic theory. These approaches will be used in the future.

In works $[9,10]$ the importance of evaluating the effectiveness of investment projects in market conditions is noted. The focus is on cash flow modeling, including all cash receipts and expenses related to the project for the pay period, taking into account the possibility of using different currencies. The authors highlighted the principle of positivity and maximum effect, the time factor, forthcoming expenses and revenues, comparisons "with the project" and "without the project", the presence of different project participants taking into account all the most real consequences of the project. They demonstrated multi-stage assessment accounting for the impact of inflation, the impact of uncertainties and risks (in quantitative form).

The project throughout its entire life cycle is under consideration and the conditions and the impact of working capital requirements on the efficiency of investment projects are compared.

E.G. Dolan and D.E. Lindsey point out that it is necessary to distinguish between external and internal production expenses. Full expenses (economic expenses), in addition to production expenses (accounting expenses), include normal profits as the minimum value, upon which it makes sense to deal with entrepreneurship [11]. The authors in their conceptual study substantiated the difference between accounting and economic costs.

However, despite significant scientific achievements, under modern conditions of management, state bodies of local authority generate new theoretical and practical problems that require solutions, including the improvement of work organization of their administrative apparatus and timely conducting the managerial control over income and expenses incurred for their maintenance.

Within the framework of this article, scientific works on the study of data mining methods, as well as decisionmaking based on these analyses, are considered. The authors of the article [12] applied a scientific econometric approach to determine the general presence and strength of the relationship between the economic indicators of large industrial enterprises in the region of Ukraine. The most significant coefficients of the analysis of the financial con- 
dition are revealed. Indeed, you need to have analyzed the object of research over a number of years to derive your own economic indicators. This allows you to justify the research results and make a prediction of the data.

A group of scientists [13] described the directions of promising research in the field of analysis and modeling of the dynamics of time series of processes in complex systems with the presence of a human factor. General information about time series and tasks of their analysis is given. The modern methods of analysis of time series of economic processes are considered. Scientists have proven that economic processes cannot be considered completely random, since they tend to self-organize and, moreover, are influenced by the memory of previous states.

The features of the main methods of analysis and forecasting of time series are presented in the works [14-23]. In addition, the authors highlight the problems and disadvantages of these methods that arise when they are applied to nonstationary time series. The article [14] provides a review of the literature on statistical methods for analyzing time series data. The author considers the following models: of exponential smoothing, of autoregressive integrated moving average, of unobservable components. The study [15] provides overview of statistical analysis of time series with an emphasis on methods of data interpretation, as opposed to methods of empirical forecasting. Scientists compare methods of processing non-stationary processes both from the point of view of non-stationarity on the average and non-stationarity in the structure.

Focusing on the fact that in the modern economy a much greater place is occupied by the estimation of dynamic models that reflect short-term and long-term relationships between economic variables, the author of the scientific study [24] analyzed the Box-Jenkins approach to identifying time series, estimated ARIMA models parameters and made forecast using these models.

Based on the analysis of literary sources, it can be concluded that there is no single view of the methodological approaches to management control in the city council for making management decisions. Thus, the implementation of theoretical achievements of scientists requires a deeper clarification of methodological developments, considering modern economic trends in the economic development and increased competition.

\section{Materials and methods}

In management control of the city council the presence of high-quality information and analytical support at all stages of its implementation is of great importance. A successfully built information and analytical support for management control will help to provide the quality of all its stages and timely process information, increasing the overall city council efficiency.

\subsection{Data analysis}

The use of various special processing techniques equipped with computer-assisted statistical information packages, such as spectral analysis, regression and correlation analyzes, guarantees a comprehensive and in-depth analysis of information. Universal mathematical approaches are successfully applied to analyze and perceive information in order to correctly forecast and develop a profitable investment strategy. Time series analysis provides insight into the causal mechanisms behind this series. The paper considers time series that describe revenues and expenses data for the local budget (general and special fund) with a complex nature of development. Simple smoothing method is used to find the evaluation of trend model parameters. The original time series is converted into a series, the values of which are the data averaged over three adjacent points in time series. The refined time series models of the special and general local budget fund revenue with the obtained trend lines is shown in figures 1, 2 .

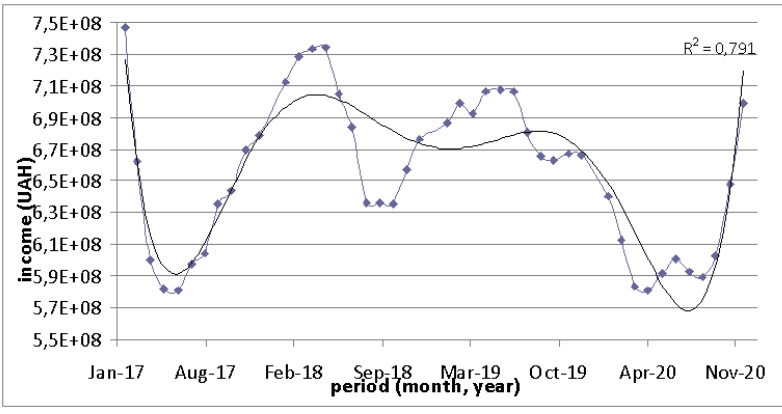

Figure 1. The refined time series model of the general local budget fund revenue

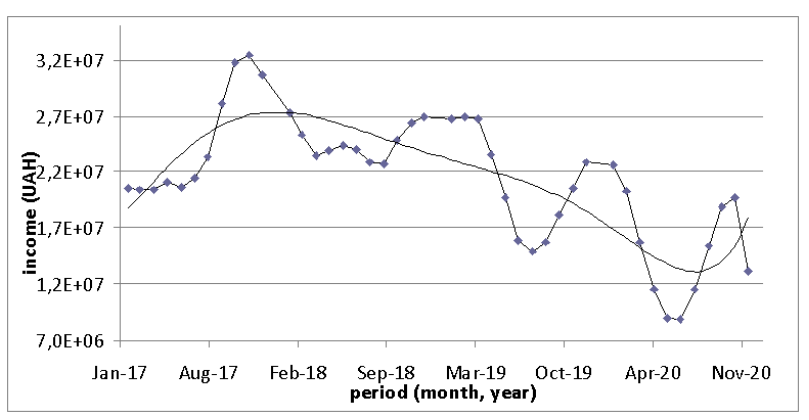

Figure 2. The refined time series model of the special local budget fund revenue

Based on the Fisher ratio (F-test), an analysis of time series stationarity describing the change in value of the completed general and special funds was carried out. Comparison of the obtained Fisher ratios for each of time series with table values for a specified value level of 0.05 made it possible to state that the value changing processes of completed general and special funds for 2017-2020 are stationary in the narrow sense.

The hypothesis of the stationarity of this process was tested on the basis of the Student's t-test [25]:

$$
t=\left|E_{1}-E_{2}\right| /\left(\sigma \sqrt{\left(1 / n_{1}+1 / n_{2}\right)}\right),
$$


where $n_{1}, n_{2}$ - the number of elements included in both parts, $E_{1}, E_{2}$ - mathematical expectations, $\sigma$ is a standard deviation of the difference in mathematical expectations. The Student's t-test of time series of general and specialized funds are, respectively, $t_{g}=0.09$ and $t_{s}=0.93$, while the table value of time series boundary is $t_{\text {tabl }}=2.03$. Data analysis made it possible to conclude that this process is stationary in terms of mathematical expectation and there is no non-random component of considered time series.

Implementation of time series analyzing methods allows you to make a reasonable forecast of changes in the studied indicators under certain conditions and properties of time series. Using this forecast, it is possible to build a strategy of actions for the future, applying the obtained indicators to carry out management control of the targeted use of transfers, implementation of targets for the establishment of a special and general local budget fund (figure 3).

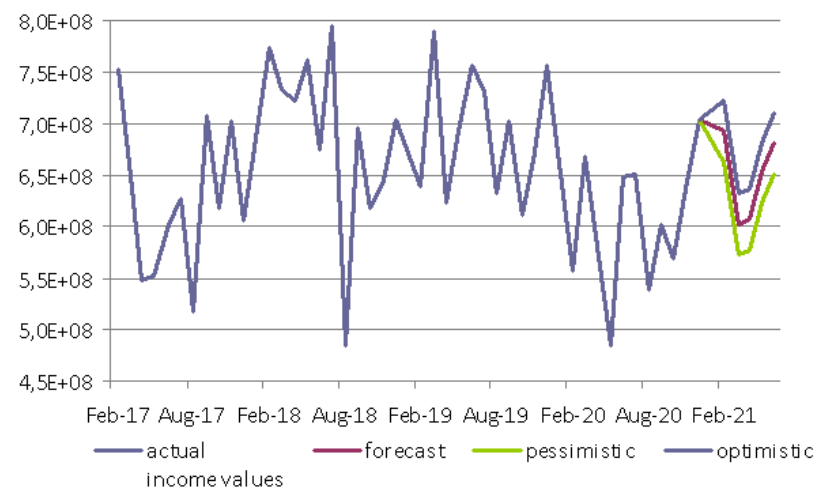

Figure 3. Actual and projected values of the general local budget fund (UAH)

Within the present study framework based on the data obtained on general and special funds expenses of the local budget in Zaporizhzhia City Council for 2017-2020, data forecast was carried out using the exponential smoothing method.

Figure 4 shows a plot of actual expenses (blue plot), an exponential forecast model with a smoothing factor of $k=0.8$ (red plot), and a forecast value with $k=0.1$ (green graph). The forecast model for $k=0.1$ is smoother and reacts more slowly to bursts in recent periods than for $k=0.8$.

The calculated forecast accuracy for the two presented models is $97.39 \%$ and $97.99 \%$, respectively. It is important to note that this model assumes regular recalculation of the forecast at the end of the last period and the appearance of new expenses data to forecast for the last period.

\subsection{Economic efficiency for carrying out management control}

Prerequisite for ensuring management control of the city council is making effective management decisions based on timely prevention and identifying errors in the formation of revenues and expenses of the general and special fund of local budget at all stages of management apparatus work.

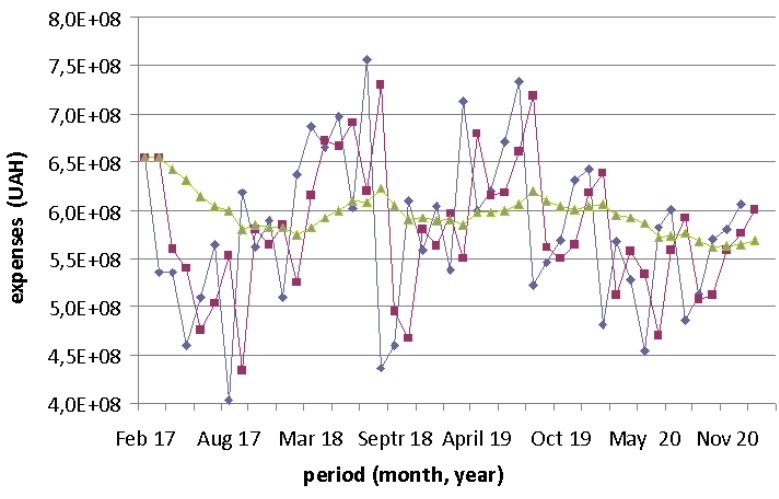

Figure 4. Actual and projected values of the general local budget fund $(\mathrm{UAH})$

The proposed concept of management control assessment, which includes information and analytical circuit, the analysis and modeling circuit, as well as a decisionmaking circuit, is shown in figure 5 .

The absolute and comparative economic efficiency of accounting expenses and the economic expenses of management control are analyzed. Statistical data was taken from the general and special fund of the Zaporizhzhia City Council from the site zp.gov.ua, and the management information from the site smida.gov.ua, youcontrol.com.ua, and also used analytical internal and forecast information. For the optimal option, the specified indicators should exceed the corresponding standard indicator of the expenses of its implementation. The developed system of indicators for evaluating management control effectiveness is based on the formed quality and performance assessment principles of its implementation [26]. Let's apply the concept of assessing the level of management control in $\mathrm{Za}$ porizhzhia City Council for January 2021 to calculate the absolute and comparative economic efficiency for its implementation (tables 1,2) in order to determine the annual economic effect of its implementation (table 3 ). The data in tables 1-3 are derived from planned internal statistics. The information for January 2021 allowed us to expand the estimate of the annual effect for comparison with the actual data.

Economic effect of management control can be calculated as the difference between annual results and incremental expenses:

$$
\begin{array}{r}
\Delta W_{m c}=\left(\Delta A_{m c 2}-\Delta A_{m c 1}\right) \cdot\left(\frac{E x_{E m c 1}}{\Delta A_{m c 1}}\right)- \\
-\left(E x_{E m c 2}-E x_{E m c 1}\right)
\end{array}
$$

The assessment of the effectiveness of management control in the Zaporizhzhia City Council for January 2021 revealed the following:

1. The absolute economic efficiency in relation to the accounting costs of management control is: the planned 8.65 , the actual 8.22 - a decrease of 0.43 . The absolute economic efficiency in relation to the economic costs of management control is equal to: the planned 7.86, the actual 7.47 - a decrease of 0.39 . Thus, the Zaporizhzhia 
Table 1. Absolute economic efficiency for carrying out management control for January 2021, UAH

\begin{tabular}{|c|c|c|c|c|}
\hline Indexes & Value & $\begin{array}{l}\text { City } \\
\text { Council } \\
\text { plan }\end{array}$ & $\begin{array}{l}\text { City } \\
\text { Council } \\
\text { fact }\end{array}$ & Deviation \\
\hline $\begin{array}{l}\text { Additional result obtained at the expense of management } \\
\text { control, UAH / year }\end{array}$ & $\Delta A_{m c}$ & 494540 & 469813 & -24727 \\
\hline Cost savings & & 494540 & 469813 & \\
\hline Accounting expense for management control, UAH & $E x_{a m c}$ & 57173 & 57173 & \\
\hline Materials, UAH / year & & 2703 & 2703 & \\
\hline Salary, UAH / year & & 40800 & 40800 & \\
\hline Accrual per Individual Entrepreneur, UAH / year & & 8976 & 8976 & \\
\hline Amortization expense, UAH / year & & 2214 & 2214 & \\
\hline Others, UAH / year & & 2480 & 2480 & \\
\hline $\begin{array}{l}\text { Indicator of absolute economic efficiency of accounting } \\
\text { expense for management control, units }\end{array}$ & $E_{m c}=\Delta A_{m c} / E x_{a m c}$ & 8,65 & 8,22 & $-0,43$ \\
\hline Regulatory profit from management control, UAH / year & $P_{r}$ & 5717 & 5717 & \\
\hline Regulatory profitability of products, units & $P A_{r}=P_{r} / E x_{a}$ & 0,10 & 0,10 & \\
\hline Economic expense of management control, UAH / year & $E x_{E m c}$ & 62890 & 62890 & \\
\hline $\begin{array}{l}\text { Indicator of absolute economic efficiency in relation to } \\
\text { the economic expense for management control, units }\end{array}$ & $E_{m c}^{\prime}=\Delta A_{m c} / E x_{e m c}$ & 7,86 & 7,47 & $-0,39$ \\
\hline $\begin{array}{l}\text { Criterion (normative indicator) of economic efficiency of } \\
\text { expenses for management control }\end{array}$ & $E_{n m c}^{\prime}$ & 7,5 & 7,5 & \\
\hline
\end{tabular}

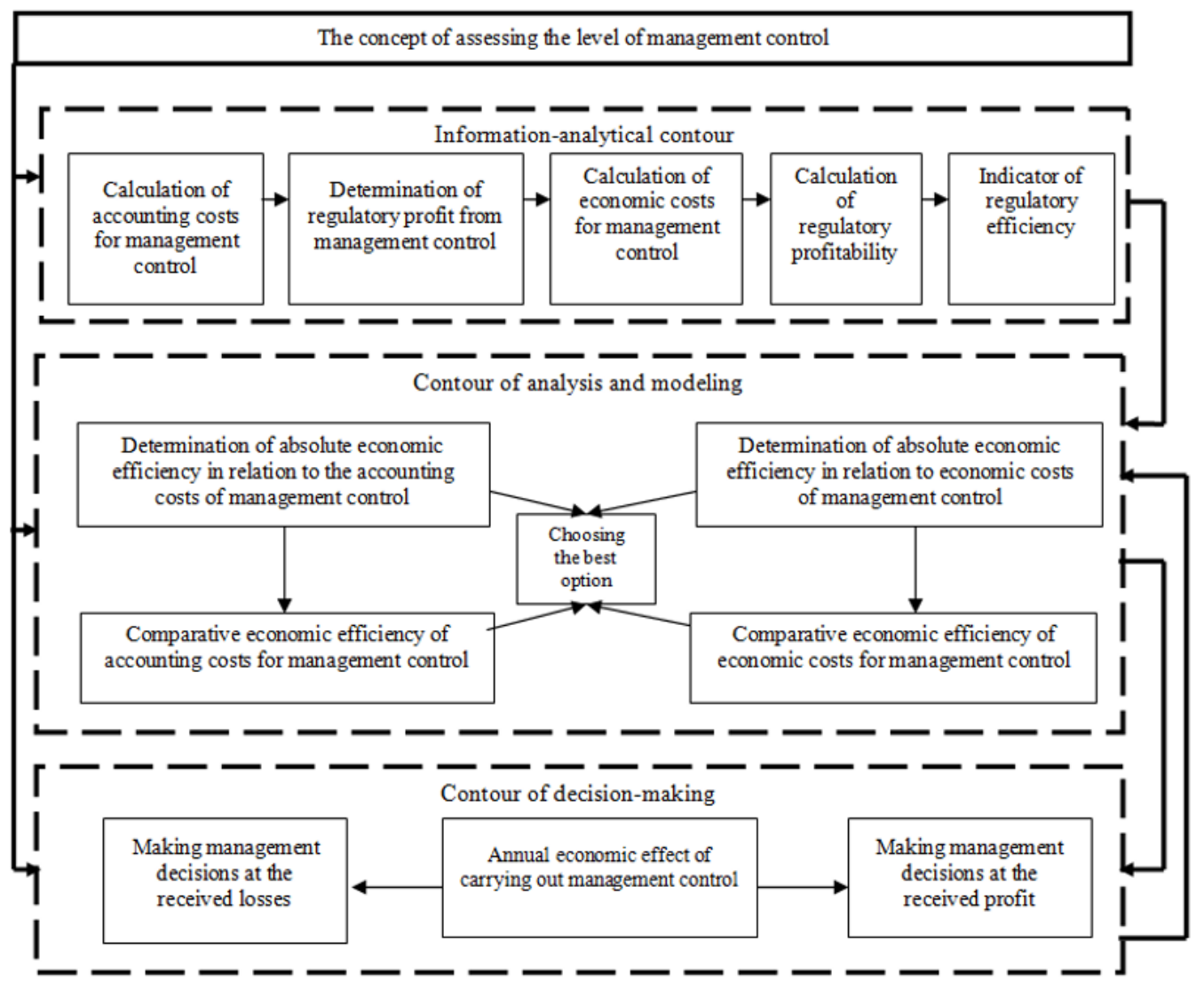

Figure 5. The concept of assessing the level of management control

City Council has a high absolute economic efficiency from the management control. The decrease in the actual figure compared to the planned was due to the lockdown, which occurred in January 2021 and reduced the amount of income received.
2. The comparative economic efficiency of accounting costs for management control is: planned 1.30, the actual $1.24-$ a decrease of 0.6. The comparative economic efficiency of economic costs of management control is equal to: the planned 1.30 , the actual $1.24-$ a decrease of 
Table 2. Comparative economic efficiency for management control in January 2021, UAH

\begin{tabular}{|c|c|c|c|c|}
\hline Indexes & Value & $\begin{array}{l}\text { City } \\
\text { Council } \\
\text { plan }\end{array}$ & $\begin{array}{l}\text { City } \\
\text { Council } \\
\text { fact }\end{array}$ & Deviation \\
\hline $\begin{array}{l}\text { Additional result obtained at the expense carry- } \\
\text { ing out of management control in the base period, } \\
\text { UAH / year }\end{array}$ & $\Delta A_{m c 1}$ & 300000 & 300000 & \\
\hline $\begin{array}{l}\text { Additional result obtained at the expense carry- } \\
\text { ing out of management control in the new period, } \\
\text { UAH / year }\end{array}$ & $\Delta A_{m c 2}$ & 494540 & 469813 & -24727 \\
\hline $\begin{array}{l}\text { Index of additional result obtained at the expense } \\
\text { carrying out of management control, units }\end{array}$ & $I_{a m c}=\Delta A_{m c 2} / \Delta A_{m c 1}$ & 1,65 & 1,57 & $-0,08$ \\
\hline $\begin{array}{l}\text { Accounting expense obtained at the expense car- } \\
\text { rying out of management control in the base pe- } \\
\text { riod, UAH / year }\end{array}$ & $E x_{a m c 1}$ & 45000 & 45000 & \\
\hline $\begin{array}{l}\text { Accounting expense obtained at the expense car- } \\
\text { rying out of management control in the new pe- } \\
\text { riod, UAH / year }\end{array}$ & $E x_{a m c 2}$ & 57173 & 57173 & \\
\hline $\begin{array}{l}\text { Index of accounting expense obtained at the ex- } \\
\text { pense carrying out of management control, units }\end{array}$ & $I_{\text {Examc }}=E x_{a m c 2} / E x_{a m c 1}$ & 1,27 & 1,27 & \\
\hline $\begin{array}{l}\text { Indicator of comparative economic efficiency of } \\
\text { accounting expense obtained carrying out of man- } \\
\text { agement control, units }\end{array}$ & $E_{C m c}=I_{a m c} I_{E x a m c}$ & 1,30 & 1,24 & $-0,06$ \\
\hline $\begin{array}{l}\text { Economic expense obtained at the expense carry- } \\
\text { ing out of management control in the base period, } \\
\text { UAH / year }\end{array}$ & $E x_{E m c 1}$ & 49500 & 49500 & \\
\hline $\begin{array}{l}\text { Economic expense obtained at the expense carry- } \\
\text { ing out of management control in the new period, } \\
\text { UAH / year }\end{array}$ & $E x_{E m c 2}$ & 62890 & 62890 & \\
\hline $\begin{array}{l}\text { Index of economic expense obtained at the ex- } \\
\text { pense carrying out of management control, units }\end{array}$ & $I_{E x E m c}=E x_{e m c 2} / E x_{e m c 1}$ & 1,27 & 1,27 & \\
\hline $\begin{array}{l}\text { Indicator of comparative economic efficiency of } \\
\text { economic expense obtained carrying out of man- } \\
\text { agement control, units }\end{array}$ & $E_{C m c}^{\prime}$ & 1,30 & 1,24 & $-0,06$ \\
\hline
\end{tabular}

Table 3. Annual economic effect of management control in January 2021, UAH

\begin{tabular}{|c|c|c|c|c|}
\hline Indexes & Value & $\begin{array}{l}\text { City } \\
\text { Council } \\
\text { plan }\end{array}$ & $\begin{array}{l}\text { City } \\
\text { Council } \\
\text { fact }\end{array}$ & Deviation \\
\hline $\begin{array}{l}\text { Additional expense for obtaining additional economic re- } \\
\text { sult from carrying out of management control, UAH / } \\
\text { year }\end{array}$ & $\left(E x_{E m c 2}-E x_{E m c 1}\right)$ & 13390 & 13390 & \\
\hline $\begin{array}{l}\text { Additional economic result from carrying out of manage- } \\
\text { ment control, UAH / year }\end{array}$ & {$\left[\begin{array}{l}\left(\Delta A_{m c 2}-\Delta A_{m c 1}\right) \cdot \\
\cdot\left(E x_{E m c 1} / \Delta A_{m c 1}\right)\end{array}\right]$} & 32099 & 28019 & -4080 \\
\hline $\begin{array}{l}\text { Annual economic effect from carrying out of manage- } \\
\text { ment control, UAH / year }\end{array}$ & $\Delta W_{m c}$ & 18709 & 14629 & -4080 \\
\hline
\end{tabular}

0.6. Thus, the Zaporizhzhia City Council has a high comparative economic efficiency from the management control. The decrease in the actual indicator compared to the planned one was due to a decrease in the amount of income, provided that the actual amount of planned expenses is observed.

3. The annual economic effect of management control is: according to the plan UAH 18,709, in fact UAH 14,629 - a decrease of UAH 4,080. Thus, the Zaporizhzhia City Council has a high annual economic effect from management control. In this study, the economic effect is achieved by obtaining a greater additional result (benefits) from managerial control in comparison with the additional costs that were spent on its implementation. As a result of the study, a relationship was revealed that shows that during management control errors are quickly identified and shortcomings in the work of administrative personnel are additionally reduced, which prevents financial sanctions, abuse and, in general, reduces the costs of the enterprise. 


\section{Conclusions}

Having studied the subject area and detailed analysis of the presented issue, the following was established:

1. Time-series revenue and cost models of the general and special fund were built on the basis of the data obtained from the local budget in Zaporizhzhia City Council for 2017-2020. The time series modeling and research describing complex changes in parameters over time makes it possible to visually analyze and timely control the analytical material of revenues and expenses of general and special funds in order to make effective management decisions.

2. The concept of assessing management control is proposed, which, in contrast to the existing ones, consists of the following contours: information and analytical, analysis and modeling, decision making. It has been tested on data from the Zaporizhzhia City Council. It is universal and can be used to assess the level of management control in all regions of Ukraine. This will make it possible to conduct a timely assessment of management control, which will increase the efficiency of work.

3. The best options for absolute and comparative economic efficiency of accounting and economic costs of management control are proposed and substantiated. This will help to calculate the annual economic effect of management control, and the result (profit or loss) will help to make effective management decisions.

4. The concept of management control assessment was tested on Zaporizhzhia City Council data. The calculation results made it possible to conclude that Zaporizhzhia City Council has a high probability of absolute and comparative economic efficiency of management control which in turn gives a high economic effect.

In the future, the proposed methodology for assessing the level of management control can be used in the work of state bodies at all levels of government.

\section{References}

[1] S. Gschwantner, M. Hiebl, J Manag Control 27, 371 (2016)

[2] R. Simons, Levers of Control: How Managers Use Innovative Control Systems to Drive Strategic Renewal (Harvard Business School Press, Boston, 1995)

[3] R. Savchenko, N. Savchenko, Ekonomika ta derzhava 9, 70 (2015)

[4] A. Junevicius, R. Daugeliene, J. Jurkeviciene, P. Orzekauskas-Nussbaum, Engineering Economics 28, 421 (2017)
[5] R. Chenhall, K. Langfield-Smith, European Management Journal 25, 266 (2007)

[6] S. Saliga, Formation of financial security of business entities on the basis of tax audit (ZTSNTEI, Zaporizhzhia, 2011)

[7] K. Saliga, The efficiency of economic activity of enterprises (ZTSNTEI, Zaporizhzhia, 2005)

[8] T. Melikhova, Y. Yarashykly, Investytsiyi: praktyka ta dosvid 2, 17 (2020)

[9] E. Antipenko, V. Donenko, V. Pokolenko, Y. Chupryna, D. Prykhodko, Upravlinnia rozvytkom skladnykh system 2, 6 (2010)

[10] T. Baibakova, L. Suvorova, V. Epinina, Y. Azmina, Advances in Economics, Business and Management Research 38, 34 (2017)

[11] E. Dolan, D. Lindsey, Market: microeconomic model (S-Petersburg, 1992)

[12] T. Melikhova, A. Makarenko, O. Mikhailytsa, A. Pozhuyev, CEUR Workshop Proceedings 2422, 226 (2019)

[13] E. Andrianova, S. Golovin, S. Zykov, S. Lesko, E. Chukalina, Russian Technological Journal 8(4), 7 (2020)

[14] D. Rahardja, Journal of Statistics and Management Systems 12, 1445 (2020)

[15] D.R. Cox, G. Gudmundsson, G. Lindgren, L. Bondesson, Scandinavian Journal of Statistics 8, 93 (1981)

[16] A. Bielinskyi, V. Soloviev, CEUR Workshop Proceedings 2292, 37 (2018)

[17] V. Soloviev, A. Belinskij, CEUR Workshop Proceedings 2104, 116 (2018)

[18] V. Soloviev, N. Moiseienko, O. Tarasova, CEUR Workshop Proceedings 2393, 905 (2019)

[19] V. Soloviev, A. Belinskiy, Communications in Computer and Information Science 1007, 276 (2019)

[20] V. Soloviev, S. Yevtushenko, V. Batareyev, CEUR Workshop Proceedings 2546, 87 (2019)

[21] V. Soloviev, A. Bielinskyi, O. Serdyuk, V. Solovieva, S. Semerikov, CEUR Workshop Proceedings 2732, 455 (2020)

[22] V. Soloviev, O. Serdiuk, S. Semerikov, A. Kiv, CEUR Workshop Proceedings 2713, 21 (2020)

[23] S. Semerikov, H. Kucherova, V. Los, D. Ocheretin, CEUR Workshop Proceedings 2845, 22 (2021)

[24] G. Kantorovich, Higher School of Economics Economic Journal 6, 85 (2002)

[25] V. Bukreev, S. Kolesnikova, A. Yankovskaya, Identification of regularities in time series in problems of recognition of states of dynamic objects (Tomsk Polytechnic University, 2010)

[26] T. Melikhova, in Industrial management: theory and practice, edited by V. Voronkova, N. Metelenko (ZNU, Zaporizhzhia, 2020) 